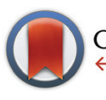

CrossMark \&click for updates

Cite this: Dalton Trans., 2015, 44 13565

Received 21st May 2015,

Accepted 15th June 2015

DOI: 10.1039/c5dt01910a

www.rsc.org/dalton

\section{Synthesis and unique reversible splitting of 14-membered cyclic aminomethylphosphines on to 7-membered heterocycles $\uparrow$}

\author{
Elvira I. Musina, ${ }^{a}$ Tatiana I. Fesenko, ${ }^{a}$ Igor D. Strelnik, ${ }^{a}$ Fedor M. Polyancev, ${ }^{a}$ \\ Shamil K. Latypov, ${ }^{a}$ Peter Lönnecke, ${ }^{b}$ Evamarie Hey-Hawkins, ${ }^{b}$ Andrey A. Karasik ${ }^{a}$ \\ and Oleg G. Sinyashin ${ }^{a}$
}

A novel type of 14-membered cyclic polyphosphine, namely 1,8-diaza-3,6,10,13-tetraphosphacyclotetradecanes $\mathbf{2}_{\mathrm{a}}-\mathbf{4}_{\mathrm{a}}$ has been synthesized by the condensation of 1,2-bis(phenylphosphino)ethane, formaldehyde and alkylamines (isopropylamine, ethylamine and cyclohexylamine) as a RRRR/SSSSstereoisomer. The structure of macrocycle $\mathbf{2}$ a was investigated by NMR-spectroscopy and X-ray crystal structure analysis. The unique reversible processes of macrocycles $\mathbf{2}_{\mathrm{a}} \mathbf{-} \mathbf{4}_{\mathrm{a}}$ splitting onto the corresponding rac- $\left(\mathbf{2}_{\mathbf{b}}-\mathbf{4}_{\mathbf{b}}\right)$ and meso- $\left(\mathbf{2}_{\mathbf{c}}-\mathbf{4}_{\mathbf{c}}\right)$ stereoisomers of 1-aza-3,6-diphosphacycloheptanes were discovered.

\section{Introduction}

The development of phosphorus-containing macrocyclic mixed-donor ligands has emerged as an important subject in coordination chemistry, because they provide characteristic chelating sites that are difficult to construct with their acyclic analogues. ${ }^{1-3}$ Such hybrid macrocyclic donors are highly promising for designing reactive and multifunctional transition metal catalysts, as, firstly, the metal center can be supported and stabilized by multidentate macrocyclic platforms, secondly, various coordination properties, such as coordination numbers, oxidation state, and geometry of the metal center are available by changing the components of the heteroatom donors, and thirdly, a conformational mobility of the ligands is controllable by a suitable choice of the bridging atoms/ groups between donor atoms. The macrocyclic multidentate phosphine ligands as formal analogues of the crown ethers hold promise as incredibly stable ligands for applications requiring robust complexes, such as radioactive metal complexes for use as radiopharmaceuticals, ${ }^{4}$ for the stable $\mathrm{Ni}$ (II) complexes with direct metal-borohydride coordination as

\footnotetext{
${ }^{a}$ A.E. Arbuzov Institute of Organic and Physical Chemistry of KSC RAS, Arbuzov str. 8, Kazan, 420088, Russian Federation. E-mail: elli@iopc.ru; Fax: +(007)8432732253; Tel: $+(007) 8432734893$

${ }^{b}$ Institute of Inorganic Chemistry, Leipzig University, Johannisallee 29, 04103 Leipzig, Germany. E-mail: hey@uni-leipzig.de; Fax: +(0049)341973319; Tel: $+(0049) 3419736151$

$\dagger$ Electronic supplementary information (ESI) available: 1D/2D NMR spectra of macrocycle 2a; ${ }^{1} \mathrm{H}_{-}{ }^{13} \mathrm{C} /{ }^{1} \mathrm{H}-{ }^{15} \mathrm{~N} /{ }^{1} \mathrm{H}_{-}{ }^{31} \mathrm{P}$ HMBC correlation experiments; kinetics of splitting of 2a; X-ray crystallography. CCDC 1060031. For ESI and crystallographic data in CIF or other electronic format see DOI: 10.1039/c5dt01910a
}

potential hydrogenation catalysts, ${ }^{5}$ and $\mathrm{Cr}$ (II) complexes as reducing agents for the catalytic production of hydrazine and/ or ammonia from nitrogen. ${ }^{6}$

It has been over 35 years since the first macrocyclic phosphine ligands were synthesized and few strategies have been designed for their synthesis. However, macrocyclic phosphine ligands have been difficult to synthesize stereoselectively in a good yield and only a handful of synthetic methods have shown broad applicability in terms of the ring sizes, functional groups, and metal complexes that can be obtained. ${ }^{1,3}$

The convenient route to macrocyclic polydentate $\mathrm{P}, \mathrm{N}$ ligands by the condensation of primary phosphines or secondary bisphosphines with formaldehyde and primary amines or diamines was developed in our laboratory. This method for the design of macrocyclic polyphosphines was based on the principles of covalent self-assembly and was successfully used for the stereoselective synthesis of macrocyclic aminomethylphosphines: 16-, 18-, 20-membered corands and 28-, 36- and 38-membered cyclophanes. ${ }^{7}$ The distinctive feature of the covalent self-assembly processes is their ability to self-correct, when the "incorrect" intermediate is able to decompose into starting compounds due to the reversibility of the reaction. These compounds react further to give a more thermodynamically stable "correct" product. The $\mathrm{P}-\mathrm{CH}_{2}-\mathrm{N}$ fragments of aminomethylphosphines are labile enough for the realization of self-assembly processes. It was shown that lability of aminomethylphosphines plays a key role for the stereoconversion between $R S$ - and $R R / S S$ isomers of 1-aza-3,6-diphosphacycloheptanes $^{8}$ and 16-membered macrocycles as well as alternative formation of only RSSR or RRRR/SSSS isomer in the row of 16-, 18and 20-membered cyclic aminomethylphosphines. ${ }^{7,9}$ 
The interaction of 1,2-bis(hydroxymethylphenylphosphino)ethane with primary aryl- and benzylamines gives only 7-membered 1-aza-3,6-diphosphacycloheptanes as thermodynamically more stable products ${ }^{8}$ in contrast to hydroxymethyl derivatives of 1,3-, 1,4- and 1,5-bisphosphines giving 16-, 18- and 20-membered cyclic tetraphosphines. ${ }^{7}$ However the formation of a 14membered macrocycle was suggested as an intermediate of interconversion of rac- and meso-isomers of 1-aza-3,6diphosphacycloheptanes. ${ }^{8 b}$

Here we reported the synthesis and crystal structure of novel 14-membered aminomethylphosphines and their unique ability to undergo a reversible splitting on to two 7-membered 1-aza-3,6-diphosphacycloheptanes in solutions.

\section{Results and discussion}

\section{Synthesis}

It has been shown that sufficient basicity of primary amines is one of the key requirements for the realization of self-assembly during Mannich type condensation. The macrocycles $\mathbf{2}_{\mathrm{a}} \mathbf{- 4} \mathrm{a}$ were obtained by Mannich-like condensation of an equimolar mixture of racemic $R R / S S$ - and $R S$-isomers of 1,2-bis(hydroxymethylphenylphosphino)ethane $\mathbf{1}$ with highly basic isopropylamine, ethylamine, and cyclohexylamine respectively in DMF (Scheme 1). It should be underlined that less basic aryl- or benzylamines in ethanol gave only 7 -membered cycles as a result of analogous condensations. ${ }^{8}$

In all cases ${ }^{31} \mathrm{P}$ NMR spectra of the reaction mixtures in DMF (after $c a$. 1-2 hours) show three main signals in the region -27 to $-37 \mathrm{ppm}$ which were assigned to the macrocyclic corands $2 \mathbf{2}-\mathbf{4 a}$ and to rac- $(\mathbf{2 b}-\mathbf{4 b})$ and meso- $(\mathbf{2 c - 4 c})$ isomers of the corresponding 1-aza-3,6-diphosphacycloheptanes. However the signals of a few acyclic half-products were also registered.

After heating the reaction mixture at $60-70{ }^{\circ} \mathrm{C}$ followed by cooling white crystalline products in the yields of $59 \%, 26 \%$ and $20 \%$ for $2_{\mathrm{a}}, \mathbf{3}_{\mathrm{a}}$ and $\mathbf{4}_{\mathrm{a}}$ respectively were isolated. The isolated macrocycles $\mathbf{2}_{\mathrm{a}}-\mathbf{4}_{\mathrm{a}}$ are insoluble in DMF and acetone, but are soluble in benzene, toluene and chloroform. The ESI-MS spectra of these compounds display the peaks, the $\mathrm{m} / \mathrm{z}$ values and isotopic patterns fitted completely with the stoichiometry of macrocycles $\mathbf{2}_{\mathrm{a}} \mathbf{- \mathbf { 4 } _ { \mathrm { a } }}$. In the ${ }^{1} \mathrm{H}$ and ${ }^{31} \mathrm{P}$ NMR spectra of $\mathbf{2}_{\mathrm{a}}-\mathbf{4}_{\mathrm{a}}$ recorded immediately after the dissolution in $\mathrm{C}_{6} \mathrm{D}_{6}$ only one set of signals was registered evidencing the formation of only one isomer.

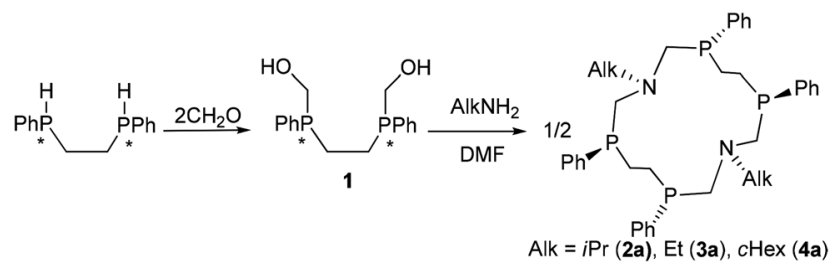

Scheme 1 Synthesis of macrocycles $2 a-4 a$.

\section{NMR data}

Complete structure elucidation of the title compounds was accomplished by a variety of 1D/2D correlation NMR experiments (COSY, HSQC, ${ }^{1} \mathrm{H}_{-}{ }^{13} \mathrm{C} /{ }^{1} \mathrm{H}^{-15} \mathrm{~N}^{1} \mathrm{H}^{-31} \mathrm{P}$ HMBC) ${ }^{10,11}$ 2D $\operatorname{DOSY}^{12,13}$ and 1D DPFGNOE ${ }^{14}$ techniques were used to measure self-diffusion coefficients and NOEs, respectively. The efficiency of the NMR approach for total macrocyclic tetraphosphine structure elucidation has been demonstrated recently. ${ }^{15}$ Related 1D/2D NMR spectra can be obtained in the ESI (Fig. S1-S29†).

The chemical structure of the titled 14-membered macrocycles can be established practically "directly" through a variety of internuclear NMR connectivities starting from P- and $\mathrm{N}$-substituents (e.g. for $\mathbf{2}_{\mathrm{a}} \mathrm{Fig}$. 1). Characteristic NOE's between $\mathrm{CH}$ (i-Pr) and $\mathrm{NCH}_{2}^{\mathrm{ax}}{ }_{2} \mathrm{P}, \mathrm{Me}^{\mathrm{in}}$ (i-Pr) and $\mathrm{NCH}^{\mathrm{ax}}{ }_{2} \mathrm{P}$, and $\mathrm{Me}^{\text {out }}$ (i-Pr) and $\mathrm{NCH}^{\mathrm{eq}}{ }_{2} \mathrm{P}$ allow unequivocal assignment of $i n-$ and out-orientation towards macrocycle methyl groups of the isopropyl substituent.

One singlet in ${ }^{31} \mathrm{P}$ spectra and only one set of signals for each type of proton in ${ }^{1} \mathrm{H}$ spectra of $\mathbf{2}_{\mathrm{a}} \mathbf{-} \mathbf{4}_{\mathrm{a}}$ suggest high overall symmetry of their 3D structures, viz. there are four magnetically equivalent fragments that can be superimposed by symmetry operation (Fig. 1c). Such high symmetry can be well explained by the fast exchange (on the NMR time scale) between two degenerate conformations that occur through intramolecular rotations around $\mathrm{P}-\mathrm{CH}_{2}-\mathrm{N}-\mathrm{CH}_{2}-\mathrm{P}$ bonds with synchronous inversions of both nitrogen's LPs (Fig. 1c). It is interesting to note that the magnetic environments of each i-Pr's methyl group do not change during this process, e.g. one methyl (in) is always oriented inside while another (out) is always outside with respect to the macrocycle cavity. Thus configurations of phosphorus atoms of both $\mathrm{P}-\mathrm{CH}_{2}-\mathrm{N}-\mathrm{CH}_{2}-\mathrm{P}$ fragments have to be the same otherwise i-Pr's methyls would be dynamically equivalent and resonate as a single doublet. On the other hand the $\mathrm{P}^{-} \mathrm{CH}_{2}-\mathrm{CH}_{2}-\mathrm{P}$ moiety resonates in ${ }^{1} \mathrm{H}$ spectra as the $\mathrm{AA}^{\prime} \mathrm{BB}^{\prime} \mathrm{MM}^{\prime}$ spin system with large vicinal spinspin couplings $\left(J_{\mathrm{AB}^{\prime}}=c a .14 \mathrm{~Hz}, J_{\mathrm{A}^{\prime} \mathrm{B}}=c a .15 \mathrm{~Hz}\right)$ that suggests trans orientation of two ending phosphorus and opposite directions of their LP's with respect to the macrocycle plane.

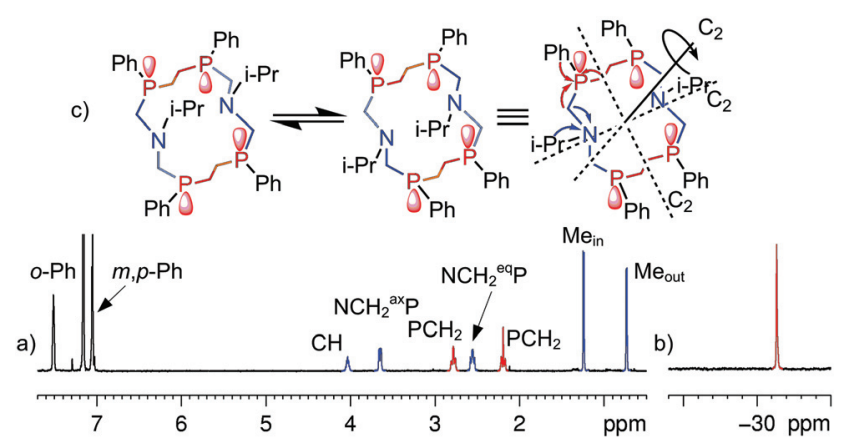

Fig. $1{ }^{1} \mathrm{H}$ (a) and ${ }^{31} \mathrm{P}$ (b) NMR spectra of $2_{\mathrm{a}}$ in $\mathrm{C}_{6} \mathrm{D}_{6}$ at $T=303 \mathrm{~K}$; (c) schematic representation of the macrocycle conformations in exchange and the main ${ }^{1} \mathrm{H}-{ }^{15} \mathrm{~N}$ (blue) $/{ }^{1} \mathrm{H}-{ }^{31} \mathrm{P}$ (red) $\mathrm{HMBC}$ correlations. 
Thus, NMR spectra of 2 a correspond to the $S_{\mathrm{P}} S_{\mathrm{P}} S_{\mathrm{P}} S_{\mathrm{P}}$ $\left(R_{\mathrm{P}} R_{\mathrm{P}} R_{\mathrm{P}} R_{\mathrm{P}}\right)$ isomer with three symmetry $C_{2}$ axis (passing through two nitrogens, through the middle of $\mathrm{CH}_{2}-\mathrm{CH}_{2}$ bonds of the $\mathrm{P}-\mathrm{CH}_{2}-\mathrm{CH}_{2}-\mathrm{P}$ moiety and orthogonal to the macrocycle plane, Fig. 1c).

Similar NMR characteristics of $\mathbf{2 a}, \mathbf{3 a}$ and $\mathbf{4 a}$ (ESI, Fig. S1$\mathrm{S} 29 \dagger)$ let us to conclude that other macrocycles $(3 \mathbf{a}, \mathbf{4 a})$ were also isolated as one enantiomeric pair rac- $\left(S_{\mathrm{P}} S_{\mathrm{P}} S_{\mathrm{P}} S_{\mathrm{P}}\right.$ $\left.\left(R_{\mathrm{P}} R_{\mathrm{P}} R_{\mathrm{P}} R_{\mathrm{P}}\right)\right)$ isomers. The formation of $S_{\mathrm{P}} S_{\mathrm{P}} S_{\mathrm{P}} S_{\mathrm{P}} / R_{\mathrm{P}} R_{\mathrm{P}} R_{\mathrm{P}} R_{\mathrm{P}}$ isomers obeys the recently formulated rule - "If the phosphorus atoms in the macrocycle are linked by an aliphatic chain consisting of an even number of methylene groups, the $S_{\mathrm{P}} S_{\mathrm{P}} S_{\mathrm{P}} S_{\mathrm{P}} / R_{\mathrm{P}} R_{\mathrm{P}} R_{\mathrm{P}} R_{\mathrm{P}}$ isomer is formed". 9

\section{X-Ray structure}

$\mathrm{X}$-ray analysis of the isolated product $\mathbf{2}_{\mathbf{a}}$ indicates that the $S_{\mathrm{P}} S_{\mathrm{P}} S_{\mathrm{P}} S_{\mathrm{P}} / R_{\mathrm{P}} R_{\mathrm{P}} R_{\mathrm{P}} R_{\mathrm{P}}$ isomer of the 14 -membered corand was formed in the course of the reaction (Fig. 2).

Two enantiomers of $\mathbf{2}_{\mathbf{a}}$, being arranged as separate columns, form a true racemic mixture. Conformation of the cycle is similar to that of the $S_{\mathrm{P}} S_{\mathrm{P}} S_{\mathrm{P}} S_{\mathrm{P}} / R_{\mathrm{P}} R_{\mathrm{P}} R_{\mathrm{P}} R_{\mathrm{P}}$ isomer of 18membered 1,10-diaza-3,8,12,17-tetraphosphacyclooctadecane ${ }^{9}$ and differs only by the length of the hydrocarbon bridge between phosphorus atoms (4.477 $\AA$ and $6.928 \AA$ for 14 - and 18-membered macrocycles respectively) (Fig. 3). The P...P-distances between phosphorus atoms bridged by the $\mathrm{CH}_{2}-\mathrm{N}-\mathrm{CH}_{2}$ fragment have similar values (4.738 and $4.525 \AA$ ) for 14 - and 18-membered macrocycles respectively.

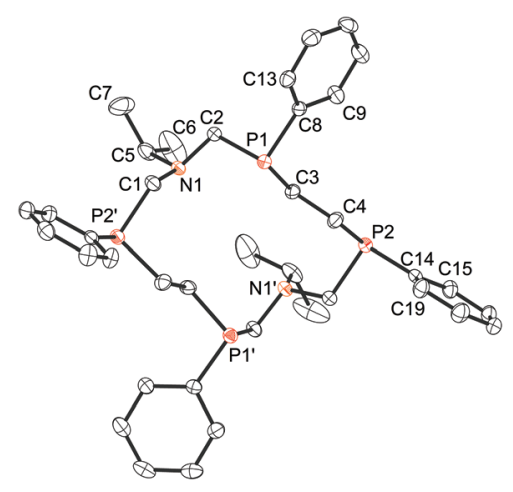

Fig. 2 Molecular structure of $2 a$.

a)

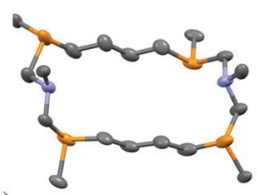

Fig. 3 Conformation of 18-membered macrocycles.
According to Dale's nomenclature the conformation of the macrocycle 2 a can be designated as the non-diamond lattice biangular [77]. In the biangular [77] conformations as well as in the [99] conformations for the 18-membered macrocycle, one half of a macrocycle, $-\mathrm{CH}_{2} \mathrm{P}\left(\mathrm{CH}_{2}\right)_{n} \mathrm{PCH}_{2} \mathrm{~N}-$, is the rotated analogue (by $2 \pi / 2$ radians) of the other with the same configurations at the asymmetric phosphorus atoms (SSSS or RRRR) and opposing orientations of their lone pair of electrons relative to each other. The substituents at the nitrogen atoms in $\mathbf{2 a}$ are located on the one side of the macrocyclic plane. The nitrogen atoms are trigonal pyramidal (the sum of angles is $335.75^{\circ}$ ). The phenyl substituents on the phosphorus atoms are located equatorial and alternating relative to the macrocycle plane.

\section{Reversible splitting of $2 a-4 a$ in solutions}

The lability of the $\mathrm{P}-\mathrm{CH}_{2}-\mathrm{N}$-fragment is a key property causing the self-assembly and stereoconversion processes of the cyclic aminomethylphosphines. Recently the interconversions between the stereoisomers of 1,9-diaza-3,7,11,15-tetraphosphacyclohexadecanes $^{9}$ and rac- and meso-isomers of seven-membered 1-aza-3,7-diphosphacycloheptanes ${ }^{8}$ in solutions were reported. The 14-membered heterocycle was supposed to be the intermediate of the conversion of seven-membered heterocycles. $^{8 b}$

It has been shown that the titled 14-membered macrocycles (2a-4a) are not stable in the solution. After half an hour two additional sets of signals appeared in the NMR spectra (e.g. Fig. 4). Intensities of new sets of signals increased with time while the signals ascribed to the 14-membered macrocycle diminished. Finally, after $c a .14$ days the system changed significantly. ${ }^{1} \mathrm{H}$ and ${ }^{31} \mathrm{P}$ spectra (Fig. 4a and b) corresponded to the mixture of the three compounds with integral intensities as ca. $75(\mathbf{2 b}-\mathbf{4 b}): 22(\mathbf{2 c - 4 c}): 3(\mathbf{2 a}-\mathbf{4 a})$. The quantity of macrocycles $\mathbf{2 a - 4 a}$ in the equilibrium mixture is only $2-6 \%$. The isomers $\mathbf{2} \mathbf{b}-\mathbf{4 b}$ noticeably prevailed in the equilibrium (73-83\%), and the amount of $\mathbf{2 c - 4 c}$ isomers is $15-25 \%$.

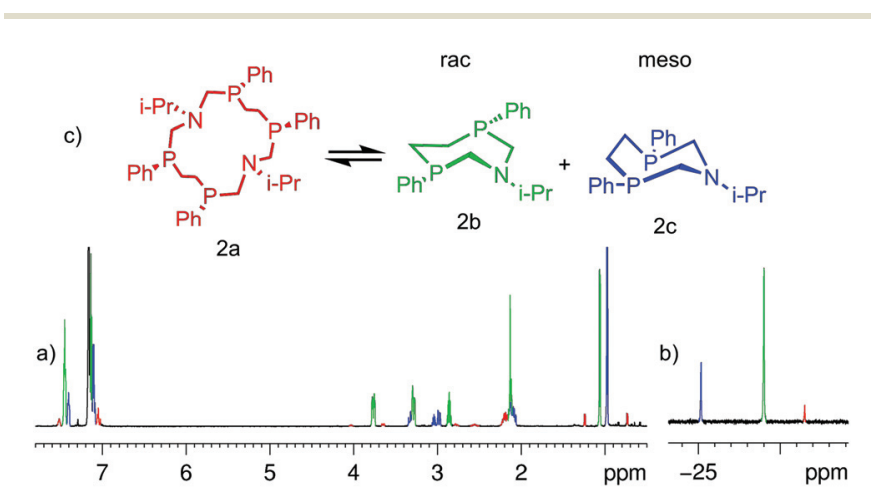

Fig. $4{ }^{1} \mathrm{H}$ (a) and ${ }^{31} \mathrm{P}$ (b) NMR spectra of $\mathbf{2}_{\mathrm{a}}, \mathbf{2}_{\mathrm{b}}$ and $\mathbf{2}_{\mathrm{c}}$ (correspondingly colored) in $\mathrm{C}_{6} \mathrm{D}_{6}$ at $T=303 \mathrm{~K}$ after ca. 14 days. (c) Schematic representation of the macrocycle and structures of the 7-membered isomers. The signals on the spectra are colored respectively. 
The signals of two new components in ${ }^{1} \mathrm{H}$ and ${ }^{31} \mathrm{P}$ spectra are situated in the same regions and have the same intensity and multiplicity relationships as described in 7-membered heterocycles ${ }^{8}$ suggesting that they have chemically close structures. So, it can be well hypothesized that in these cases the 14-membered macrocycles are disassembled onto the corresponding halves to give two molecules of 1-aza-3,6-diphosphacycloheptanes in solution (Fig. 4c).

${ }^{1} \mathrm{H}-{ }^{13} \mathrm{C} /{ }^{1} \mathrm{H}-{ }^{15} \mathrm{~N} /{ }^{1} \mathrm{H}-{ }^{31} \mathrm{P}$ HMBC correlation experiments allow us to unequivocally ascribe signals in NMR spectra to each of the components of the mixture (ESI Fig. S7-S29†).

Indeed, according to 2D DOSY spectra for 2 self-diffusion coefficients' (SDC) of new species in solution are $c a$. equal and notably higher $\left(1.78 \times 10^{-9} \mathrm{~m}^{2} \mathrm{~s}^{-1}\right)$ than that for the initial 14-membered macrocycle $\left(1.42 \times 10^{-9} \mathrm{~m}^{2} \mathrm{~s}^{-1}\right)$ (ESI Fig. S13 $\dagger$ ). Thus by taking into account Einstein-Stokes relationship between SDC and effective molecular volume, ${ }^{16}$ it can be figured out that weight (or volume) of new products is $c a$. two times less than that of the initial 14-membered macrocycle. Thus based upon these data we can conclude that new signals correspond to the 7-membered heterocycles. Similar relationships for SDC of different isomers were also observed for 3 (ESI Fig. S21†).

Unequivocal assignment of rac- and meso-isomers can be done on symmetry consideration. For example, two i-Pr's methyls of 2 are equivalent in the meso-form but they should resonate separately in the rac-isomer like in the 14-membered macrocycle. Thus in $\mathrm{C}_{6} \mathrm{D}_{6}$ solution the rac-isomer dominates $\left(\delta_{\mathrm{P}}=-29.0 \mathrm{ppm}\right)$, the meso-form $\left(\delta_{\mathrm{P}}=-25.2 \mathrm{ppm}\right)$ being less populated. In a similar manner for 3 and $\mathbf{4}$, equivalence/nonequivalence of $\mathrm{N}-\mathrm{CH}_{2}-\mathrm{CH}_{3}$ and $\mathrm{N}$-cyclohexyl protons was used to differentiate meso-versus rac-isomers.

This assignment is also strongly supported by GIAO ${ }^{31} \mathrm{P}$ chemical shift (CS) data. According to calculations (Table 1) for $\mathbf{2}$ and $\mathbf{4}$ macrocycles $(\mathbf{2 a}, \mathbf{4 a}$ ) should resonate at a higher field while the meso-isomers $(\mathbf{2 c}, \mathbf{4 c})$ are expected to be at a lower field than rac-isomers $(\mathbf{2} \mathbf{b}, \mathbf{4 b})$. In the case of $\mathbf{3}$ a reverse relationship is expected due to slightly different conformational preference around the $\mathrm{N}-\mathrm{R}$ bond. All this is in full agreement with experimental findings (Table 1 ).

The NMR monitoring of the interconversion showed that two processes take place: the splitting of the macrocycle onto

Table 1 Calculated and experimental ${ }^{31} \mathrm{P}$ CS's

\begin{tabular}{llll}
\hline & \multicolumn{2}{l}{ Compound } & \\
\cline { 2 - 4 } & $\mathbf{2}$ & $\mathbf{3}$ & $\mathbf{4}$ \\
& $\delta_{\text {calc }} / \delta_{\exp }{ }^{a}$ & $\delta_{\text {calc }}{ }^{b} / \delta_{\exp }$ & $\delta_{\text {calc }} / \delta_{\exp }$ \\
\hline 14-Memb. (a) & $-33.5 /-31.5$ & $-33.7 /-31.5$ & $-33.3 /-31.7$ \\
rac $(\mathbf{b})$ & $-32.3 /-29.0$ & $-43.7 /-36.5$ & $-32.3 /-30.0$ \\
meso $(\mathbf{c})$ & $-22.8 /-25.2$ & $-36.9 /-33.5$ & $-23.1 /-26.2$ \\
a Experimental & ${ }^{31} \mathrm{P}$ NMR CSs of 2a,b,c-4a,b,c in $\mathrm{C}_{6} \mathrm{D}_{6}$ at $303 \mathrm{~K} .{ }^{b}$ For 3 \\
in rac- and meso-isomers CSs are averaged between two almost \\
isoenergetical conformations around the N-R bond.
\end{tabular}

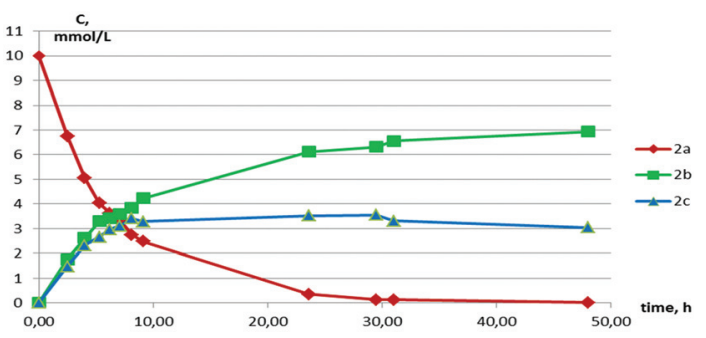

Fig. 5 A plot of the concentration of $2 a, 2 b$ and $2 c$ on the time of the standing in the solution (initial concentration of $2 \mathrm{a}$ is $10 \mathrm{mmol} \mathrm{L}^{-1}, T=$ $343 \mathrm{~K}$, solvent $-\mathrm{C}_{6} \mathrm{D}_{6}$ ).

$R R / S S$ - and $R S$-isomers of the 7-membered heterocycle and the stereoconversion between those isomers (Fig. 5).

The rate of both the processes is increased by the increase of the initial concentration of the macrocycle (from $10 \mathrm{mmol}$ $\mathrm{L}^{-1}$ to $40 \mathrm{mmol} \mathrm{L}^{-1}$, ESI Tables $\mathrm{S} 4$ and $\mathrm{S} 5 \dagger$ ) and temperature (295.5 K or $343 \mathrm{~K}$ ) (ESI Tables S5 and S6 $\dagger$ ). Moreover, the presence of $10 \%$ of $p$-toluenesulfonic acid as a proton source accelerates the dissociation and the stereoconversion processes (ESI, Table S7†). The equilibrium is established during ca. $30 \mathrm{~h}$ in contrast to $c a .340 \mathrm{~h}$ for acid free mixtures with the same initial concentration and temperature (ESI Tables S5 and $\mathrm{S} 7 \dagger$ ). The relative content of the products $\mathbf{a}, \mathbf{b}$ and $\mathbf{c}$ in the final equilibrium mixtures does not change in all cases. So, we suppose that the found interconversion processes are catalyzed by protons from acid or water traces.

Unexpectedly, in spite of prevalence of $\mathbf{2 b}-\mathbf{4 b}(73-83 \%)$ only crystals of macrocycles $\mathbf{2 a - 4 a}$ were obtained in nearly quantitative yields after the slow evaporation of solvent from equilibrium mixtures. Moreover, only the signal of the 14-membered cycle was registered in the NMR spectra of the sample that was obtained after the solvent removal from the equilibrated mixture predominantly containing 7-membered cycles and the subsequent addition of the fresh solvent. These results indicate that the splitting processes are reversible and the difference between formation energies of the 14-membered and 7-membered heterocycles is not significant and crystal packing energy could cause the back formation of the 14-membered heterocycle, whereas the stabilization of seven-membered forms in solution may be well explained by the impact of solvent effects and entropic contribution.

\section{Conclusions}

In summary, we have demonstrated the effectiveness of the covalent self-assembly approach for the stereoselective synthesis of 14-membered macrocyclic tetrakisphosphines as the $S_{\mathrm{P}} S_{\mathrm{P}} S_{\mathrm{P}} S_{\mathrm{P}} / R_{\mathrm{P}} R_{\mathrm{P}} R_{\mathrm{P}} R_{\mathrm{P}}$ stereoisomer thereby expanding the row of 16-, 18- and 20-membered macrocyclic aminomethylphosphines and showing the versatility of Mannich-like condensation reaction between $\alpha, \omega$-bis(arylphosphino)alkanes, formaldehyde and primary amines. In contrast to the higher 
macrocycles the 14-membered aminomethylphosphines undergo the unusual process of the reversible cycle splitting onto two molecules of 1-aza-3,6-diphosphacycloheptanes. The splitting ability of 14-membered cycles should be taken into account for further design of transition metal complexes and catalytic active systems on their basis, e.g. catalysts for electrochemical hydrogen transformations. ${ }^{17}$

\section{Experimental}

All manipulations were carried out using standard highvacuum and dry-nitrogen techniques. Solvents were dried and degassed prior to use and stored under a nitrogen atmosphere.

\section{NMR spectroscopy}

All NMR experiments were performed with a Bruker AVANCE-600 spectrometer (14.1 T) equipped with a $5 \mathrm{~mm}$ diameter gradient inverse broad band probehead and a pulsed gradient unit capable of producing magnetic field pulse gradients in the $z$-direction of $53.5 \mathrm{G} \mathrm{cm}^{-1}$. Frequencies are 600.13 MHz in ${ }^{1} \mathrm{H}$ NMR, $242.94 \mathrm{MHz}$ in ${ }^{31} \mathrm{P}$ NMR, $150.90 \mathrm{MHz}$ in ${ }^{13} \mathrm{C}$ NMR, and $60.81 \mathrm{MHz}$ in ${ }^{15} \mathrm{~N}$ NMR experiments. For ${ }^{1} \mathrm{H}^{13}{ }^{13} \mathrm{C}$ correlations the HSQC experiment was optimized for $J=165 \mathrm{~Hz}$. For ${ }^{1} \mathrm{H}^{-13} \mathrm{C}$ long range correlations the HMBC experiment was optimized for $J=8 \mathrm{~Hz}$. For ${ }^{1} \mathrm{H}^{-31} \mathrm{P}$ long range correlations the HMBC experiment was optimized for $J=8 \mathrm{~Hz}$. For ${ }^{1} \mathrm{H}^{-15} \mathrm{~N}$ long range correlations the HMBC experiment was optimized for $J=6 \mathrm{~Hz}$. DOSY experiments were performed with ledbpgp2s, using a stimulated echo sequence and two spoil gradients. NOE experiments were performed using 1D DPFGNOE techniques. Samples ( $c a .1 \mathrm{mg}$ ) were prepared by dissolving in $0.6 \mathrm{~mL}$ of the corresponding solvent $\left(\mathrm{C}_{6} \mathrm{D}_{6} 99.5 \%\right.$ $\mathrm{D}$ (Sigma-Aldrich, Germany)) under an inert atmosphere (Ar) and were placed in standard NMR tubes (Norell, USA). Chemical shifts are reported on the $\delta(\mathrm{ppm})$ scale relative to the ${ }^{1} \mathrm{H}$ and ${ }^{13} \mathrm{C}$ signals of tetramethylsilane (TMS) $(0.00 \mathrm{ppm}) \cdot{ }^{15} \mathrm{~N}$ and ${ }^{31} \mathrm{P}$ chemical shifts were referenced to the ${ }^{15} \mathrm{~N}$ signal of $\mathrm{CH}_{3} \mathrm{CN}(235.5 \mathrm{ppm})$ and the ${ }^{31} \mathrm{P}$ signal of $85 \% \mathrm{H}_{3} \mathrm{PO}_{4}$ (0.00 ppm), respectively.

The Fourier transform pulsed-gradient spin-echo (FTPGSE) experiments $^{12,13}$ were performed by using a BPP-STE-LED (bipolar pulse pair-stimulated echo-longitudinal eddy current delay) sequence. Data were acquired with a 50.0 or $120.0 \mathrm{~ms}$ diffusion delay, with bipolar gradient pulse duration from 2.2 to $6.0 \mathrm{~ms}$ (depending on the system under investigation), a $1.1 \mathrm{~ms}$ spoil gradient pulse (30\%) and a $5.0 \mathrm{~ms}$ eddy current delay. The bipolar pulse gradient strength was varied incrementally from 0.01 to $0.32 \mathrm{~T} \mathrm{~m}^{-1}$ in 16 steps.

\section{Calculations}

The quantum chemical calculations were performed using the Gaussian 03 software package. ${ }^{18}$ Full geometry optimizations have been carried out within the framework of the DFT (PBE1PBE) method using 6-31+G(d) basis sets. As recommended ${ }^{19}{ }^{31} \mathrm{P}$ CSs were calculated at the PBE1PBE/6-311G (2d,2p) level of theory. ${ }^{31} \mathrm{P}$ CSs were referred at $\mathrm{H}_{3} \mathrm{PO}_{4}$. A linear scaling procedure was applied for correcting systematic errors. ${ }^{19}$

The ESI mass spectra were obtained on a Bruker Esquire 3000 Plus. The melting points were determined on a Boetius apparatus and are uncorrected.

Synthesis of starting 1,2-bis(phenylphosphino)ethane was carried out by the described method. All other reagents were purchased from commercial sources and used as received.

Compound 1 was synthesised by the described method from the corresponding 1,2-bis(phenylphosphino)ethane and formaldehyde. $^{8}$

1,8-Diisopropyl-3,6,10,13-tetraphenyl-1,8-diaza-3,6,10,13-tetraphosphacyclotetradecane (2). To the solution of 1 (from $0.84 \mathrm{~g}$ (3.4 mmol) 1,2-bis(phenylphosphino)ethane and $0.20 \mathrm{~g}$ $(6.7 \mathrm{mmol})$ paraform $)$ in $5 \mathrm{ml} \mathrm{DMF}$, isopropylamine $(0.20 \mathrm{~g}$, $3.4 \mathrm{mmol}$ ) in $2 \mathrm{ml}$ DMF was added. The reaction mixture was warmed at $50{ }^{\circ} \mathrm{C}$ for 7 hours. After cooling the precipitated white crystals were filtered off and washed 2 times with $5 \mathrm{ml}$ ethanol. Yield: $0.66 \mathrm{~g}, 59 \%, \mathrm{mp} \quad 159-160{ }^{\circ} \mathrm{C} .{ }^{1} \mathrm{H} \quad \mathrm{NMR}$ (600.13 MHz; $\left.\mathrm{C}_{6} \mathrm{D}_{6} ; \mathrm{ppm}\right): 7.51(8 \mathrm{H}, \mathrm{br}, o-\mathrm{Ph}), 7.02-7.08(12 \mathrm{H}$, $\mathrm{m}, m, p-\mathrm{Ph}), 4.03\left(2 \mathrm{H}, \mathrm{p},{ }^{3} J_{\mathrm{HH}} 6.6, \mathrm{CH}_{3} \mathrm{CH}\right), 3.65\left(4 \mathrm{H}, \mathrm{dd},{ }^{2} J_{\mathrm{HH}}\right.$ $\left.12.5,{ }^{2} J_{\mathrm{PH}} 4.3, \mathrm{PCH}_{2} \mathrm{~N}_{\mathrm{ax}}\right), 2.78\left(4 \mathrm{H}, \mathrm{dd},{ }^{2} J_{\mathrm{PH}} 14.7,{ }^{2} J_{\mathrm{HH}} 11.6\right.$, $\left.\mathrm{PCH}_{2}\right), 2.56\left(4 \mathrm{H}, \mathrm{dd},{ }^{2} J_{\mathrm{HH}} 12.5,{ }^{2} J_{\mathrm{PH}} 8.3, \mathrm{PCH}_{2} \mathrm{~N}_{\mathrm{eq}}\right), 2.19(4 \mathrm{H}$, $\left.\mathrm{dd},{ }^{2} J_{\mathrm{PH}} 14.7,{ }^{2} J_{\mathrm{HH}} 12.2, \mathrm{PCH}_{2}\right), 1.24\left(6 \mathrm{H}, \mathrm{d},{ }^{3} J_{\mathrm{HH}} 6.9, \mathrm{CH}_{3} \mathrm{CH}-\right.$ in), $0.73\left(6 \mathrm{H}, \mathrm{d},{ }^{3} \mathrm{~J}_{\mathrm{HH}} 6.6, \mathrm{CH}_{3} \mathrm{CH}-\right.$ out $) .{ }^{13} \mathrm{C}\left\{{ }^{1} \mathrm{H}\right\} \mathrm{NMR}$ (150.90 MHz, $\left.\mathrm{C}_{6} \mathrm{D}_{6} ; \mathrm{ppm}\right): 138.9$ (dd, ${ }^{1} J_{\mathrm{PC}} 24.0, J_{\mathrm{PC}} 5.0$, i-Ph), 133.7 (ddd, $\left.{ }^{2} J_{\mathrm{PC}} 12.5,{ }^{5} J_{\mathrm{PC}} 9.7,{ }^{6} J_{\mathrm{PC}} 9.1, o-\mathrm{Ph}\right), 129.7(\mathrm{~s}, m-\mathrm{Ph})$, 129.5 (s, $p$-Ph), 57.1 (br, AA'X spin system, ${ }^{1} J_{\mathrm{PC}}-10.2,{ }^{3} J_{\mathrm{PC}} 5.9$, $\left.{ }^{3} J_{\mathrm{PP}} 22.0,{ }^{4} J_{\mathrm{PP}} 11.1, \mathrm{PCH}_{2} \mathrm{~N}\right), 51.1\left(\mathrm{~s}, \mathrm{CH}_{3} \mathrm{CH}\right), 27.1\left(\mathrm{br}, \mathrm{AA}^{\prime} \mathrm{X}\right.$ spin system, $\left.{ }^{1} J_{\mathrm{PC}}-19.9,{ }^{2} J_{\mathrm{PC}} 13.2,{ }^{3} J_{\mathrm{PP}} 22.0,{ }^{4} J_{\mathrm{PP}} 11.1, \mathrm{P}-\mathrm{CH}_{2}\right)$, 22.7 (s, $\mathrm{CH}_{3} \mathrm{CH}-$ in), 12.7 (s, CH $\mathrm{H}_{3} \mathrm{CH}-$ out $) .{ }^{31} \mathrm{P}\left\{{ }^{1} \mathrm{H}\right\}$ NMR (242.94 MHz; $\left.\mathrm{C}_{6} \mathrm{D}_{6} ; \mathrm{ppm}\right):-31.3 .{ }^{15} \mathrm{~N}\left(60.81 \mathrm{MHz}, \mathrm{C}_{6} \mathrm{D}_{6}, \mathrm{ppm}\right)$ : 40.9. MS (ESI +$), m / z,\left(I_{\text {rel }}, \%\right): 675(73)[\mathrm{M}+\mathrm{O}+\mathrm{H}]^{+}, 681$ (73) $[\mathrm{M}+\mathrm{Na}]^{+}, 697(100)[\mathrm{M}+\mathrm{K}]^{+}$. Anal. calc. for $\mathrm{C}_{38} \mathrm{H}_{50} \mathrm{~N}_{2} \mathrm{P}_{4}: \mathrm{C}$, 69.29; H, 7.65; N, 4.25; P, 18.81. Found: C, 69.27; H, 7.67; N, $4.24 ; \mathrm{P}, 18.76 \%$.

After 14 days of standing of $2_{\mathrm{a}}$ in $\mathrm{C}_{6} \mathrm{D}_{6}$ the signals of dissociation products rac- $\left(\mathbf{2}_{\mathbf{b}}\right)$ and meso- $\left(\mathbf{2}_{\mathbf{c}}\right)$ isomers of 1-isopropyl-3,6-diphenyl-1-aza-3,6-diphosphacycloheptane prevailed.

Rac-isomer of 1-isopropyl-3,6-diphenyl-1-aza-3,6-diphosphacycloheptane $\left(\mathbf{2}_{\boldsymbol{b}}\right) .{ }^{1} \mathrm{H}$ NMR $\left(600.13 \mathrm{MHz} ; \mathrm{C}_{6} \mathrm{D}_{6} ; \mathrm{ppm}\right): 7.45$ $\left(4 \mathrm{H}, \mathrm{dd},{ }^{3} J_{\mathrm{HH}} 7.0,{ }^{3} J_{\mathrm{PH}} 6.7, o-\mathrm{Ph}\right), 7.13\left(6 \mathrm{H}, \mathrm{t},{ }^{3} J_{\mathrm{HH}} 7.0, m, p-\right.$ $\mathrm{Ph}), 3.77\left(2 \mathrm{H}, \mathrm{ddd},{ }^{2} J_{\mathrm{HH}} 13.6,{ }^{2} J_{\mathrm{PH}} 4.4,{ }^{4} J_{\mathrm{HH}} 4.4, \mathrm{PCH}_{2} \mathrm{~N}\right), 3.28$ $\left(2 \mathrm{H}, \mathrm{dd},{ }^{2} J_{\mathrm{HH}} 13.6,{ }^{4} J_{\mathrm{PH}} 3.1, \mathrm{PCH}_{2} \mathrm{~N}\right), 2.86\left(1 \mathrm{H}, \mathrm{o},{ }^{3} J_{\mathrm{HH}} 6.7\right.$, $\left.{ }^{3} J_{\mathrm{HH}} 6.4, \mathrm{CH}_{3} \mathrm{CH}\right), 2.04-2.25\left(4 \mathrm{H}, \mathrm{m}, \mathrm{PCH}_{2}\right), 1.06\left(3 \mathrm{H}, \mathrm{d},{ }^{3} \mathrm{JHH}_{\mathrm{HH}}\right.$ 6.4, $\left.\mathrm{CH}_{3} \mathrm{CH}\right), 0.97\left(3 \mathrm{H}, \mathrm{d},{ }^{3} J_{\mathrm{HH}} 6.7, \mathrm{CH}_{3} \mathrm{CH}\right) .{ }^{13} \mathrm{C}\left\{{ }^{1} \mathrm{H}\right\} \mathrm{NMR}$ (150.90 MHz, $\left.\mathrm{C}_{6} \mathrm{D}_{6} ; \mathrm{ppm}\right): 140.7$ (dd, ${ }^{1} J_{\mathrm{PC}} 10.7,{ }^{4} J_{\mathrm{PC}} 2.9$, i-Ph), $133.1\left(\mathrm{dd},{ }^{2} J_{\mathrm{PC}} 9.1,{ }^{5} J_{\mathrm{PC}} 5.7, o-\mathrm{Ph}\right), 129.4(\mathrm{~m}, m-\mathrm{Ph}), 129.3(\mathrm{~m}$, $p$ - $\mathrm{Ph}), 57.7\left(\mathrm{~m}, \mathrm{AA} \mathrm{X}^{\prime} \mathrm{X}\right.$ spin system, ${ }^{1} J_{\mathrm{PC}}-15.1,{ }^{3} J_{\mathrm{PC}} 10.5$, $\left.{ }^{3} J_{\mathrm{PP}} 11.5, \mathrm{PCH}_{2} \mathrm{~N}\right), 57.4\left(\mathrm{t},{ }^{3} J_{\mathrm{PC}} 3.6, \mathrm{CH}_{3} \mathrm{CH}\right), 27.7$ (m, $\mathrm{AA}^{\prime} \mathrm{X}$ spin system, $\left.{ }^{1} J_{\mathrm{PC}}-15.9,{ }^{2} J_{\mathrm{PC}} 14.1,{ }^{3} J_{\mathrm{PP}} 11.5, \mathrm{PCH}_{2}\right), 20.4\left(\mathrm{~s}, \mathrm{CH}_{3} \mathrm{CH}\right)$. ${ }^{31} \mathrm{P}\left\{{ }^{1} \mathrm{H}\right\} \quad \mathrm{NMR} \quad\left(242.94 \quad \mathrm{MHz} ; \quad \mathrm{C}_{6} \mathrm{D}_{6} ; \quad \mathrm{ppm}\right): \quad-29.0 . \quad{ }^{15} \mathrm{~N}$ (60.81 MHz, $\mathrm{C}_{6} \mathrm{D}_{6}, \mathrm{ppm}$ ): 42.3 .

Meso-isomer of 1-isopropyl-3,6-diphenyl-1-aza-3,6-diphosphacycloheptane $\left(2_{c}\right) .{ }^{1} \mathrm{H}$ NMR $\left(600.13 \mathrm{MHz} ; \mathrm{C}_{6} \mathrm{D}_{6} ; \mathrm{ppm}\right): 7.40$ 
(4 H, dd, $\left.{ }^{3} J_{\mathrm{HH}} 7.4,{ }^{3} J_{\mathrm{PH}} 6.3, o-\mathrm{Ph}\right), 7.11\left(6 \mathrm{H}, \mathrm{t},{ }^{3} J_{\mathrm{HH}} 7.4, m, p-\right.$ $\mathrm{Ph}), 3.26-3.35\left(2 \mathrm{H}, \mathrm{m}, \mathrm{PCH}_{2} \mathrm{~N}\right), 3.04\left(1 \mathrm{H}, \mathrm{p},{ }^{3} \mathrm{~J}_{\mathrm{HH}} 6.6, \mathrm{CH}_{3} \mathrm{CH}\right)$, $2.98\left(2 \mathrm{H}, \mathrm{dd},{ }^{2} J_{\mathrm{HH}} 14.0,{ }^{2} J_{\mathrm{PH}} 4.2, \mathrm{PCH}_{2} \mathrm{~N}\right), 2.04-2.25(4 \mathrm{H}, \mathrm{m}$, $\left.\mathrm{PCH}_{2}\right), 0.97$ (6 H, d, ${ }^{3} J_{\mathrm{HH}}$ 6.7, $\left.\mathrm{CH}_{3} \mathrm{CH}\right) .{ }^{13} \mathrm{C}\left\{{ }^{1} \mathrm{H}\right\} \quad \mathrm{NMR}$ (150.90 MHz, $\left.\mathrm{C}_{6} \mathrm{D}_{6} ; \mathrm{ppm}\right): 141.1$ (dd, ${ }^{1} J_{\mathrm{PC}} 10.7,{ }^{4} J_{\mathrm{PC}} 5.3$, i-Ph), $132.7\left(\mathrm{dd},{ }^{2} J_{\mathrm{PC}} 9.0,{ }^{5} J_{\mathrm{PC}} 8.0, o-\mathrm{Ph}\right), 129.4(\mathrm{~m}, m-\mathrm{Ph}), 129.3(\mathrm{~m}$, p-Ph), 56.9 (m, AA'X spin system, ${ }^{1} J_{\mathrm{PC}}-9.3,{ }^{3} J_{\mathrm{PC}} 2.1,{ }^{3} J_{\mathrm{PP}} 19.5$, $\mathrm{PCH}_{2} \mathrm{~N}$ ), $56.4\left(\mathrm{t},{ }^{3} J_{\mathrm{PC}} 5.9, \mathrm{CH}_{3} \mathrm{CH}\right), 23.1$ (br, $\mathrm{AA}^{\prime} \mathrm{X}$ spin system, $\left.{ }^{1} J_{\mathrm{PC}}-23.0,{ }^{3} J_{\mathrm{PC}} 15.1,{ }^{3} J_{\mathrm{PP}} 19.5, \mathrm{PCH}_{2}\right), 20.1$ (s, $\left.C \mathrm{H}_{3} \mathrm{CH}\right) .{ }^{31} \mathrm{P}\left\{{ }^{1} \mathrm{H}\right\}$ NMR (242.94 MHz; $\left.\mathrm{C}_{6} \mathrm{D}_{6} ; \mathrm{ppm}\right):-25.2 .{ }^{15} \mathrm{~N}\left(60.81 \mathrm{MHz}, \mathrm{C}_{6} \mathrm{D}_{6}\right.$, ppm): 41.3 .

1,8-Diethyl-3,6,10,13-tetraphenyl-1,8-diaza-3,6,10,13-tetraphosphacyclotetradecane (3). To the solution of $\mathbf{1}$ (from $1.6 \mathrm{~g}$ (6.5 mmol) 1,2-bis(phenylphosphino)ethane and $0.39 \mathrm{~g}$ (13.0 mmol) paraform) in $5 \mathrm{ml}$ DMF, $0.2 \mathrm{M}$ solution of ethylamine in methanol $(3.3 \mathrm{ml}, 6.6 \mathrm{mmol})$ was added. The reaction mixture was warmed at $50{ }^{\circ} \mathrm{C}$ for 1 hour. After cooling the precipitated white crystals were filtered off and washed 2 times with $5 \mathrm{ml}$ of diethyl ether. Yield: $0.54 \mathrm{~g}, 26 \%, \mathrm{mp} 129-130{ }^{\circ} \mathrm{C}$. ${ }^{1} \mathrm{H}$ NMR (600.13 MHz; C $6 \mathrm{D}_{6}$; ppm): 7.47 (8 H, br, o-Ph), 7.05 (12 H, br, $m, p-\mathrm{Ph}), 3.67\left(4 \mathrm{H}, \mathrm{d},{ }^{2} J_{\mathrm{HH}} 12.1, \mathrm{P}-\mathrm{CH}_{2}-\mathrm{N}_{\mathrm{ax}}\right), 3.45$ $\left(2 \mathrm{H}, \mathrm{dq},{ }^{2} J_{\mathrm{HH}} 14.0,{ }^{3} J_{\mathrm{HH}} 6.4, \mathrm{NCH}_{2} \mathrm{CH}_{3}\right), 2.74\left(4 \mathrm{H}, \mathrm{ddm},{ }^{2} J_{\mathrm{HH}}\right.$ 14.8, $\left.{ }^{2} J_{\mathrm{PH}} 12.0, \mathrm{PCH}_{2}\right), 2.44\left(6 \mathrm{H}, \mathrm{m}, \mathrm{PCH}_{2} \mathrm{~N}_{\mathrm{eq}}+\mathrm{NCH}_{2} \mathrm{CH}_{3}\right)$, $2.16\left(4 \mathrm{H}, \mathrm{dd},{ }^{2} J_{\mathrm{HH}} 14.8,{ }^{2} J_{\mathrm{PH}} 12.7, \mathrm{PCH}_{2}\right), 1.10\left(6 \mathrm{H}, \mathrm{t},{ }^{3} J_{\mathrm{HH}} 7.1\right.$, $\left.\mathrm{CH}_{2} \mathrm{CH}_{3}\right) .{ }^{13} \mathrm{C}\left\{{ }^{1} \mathrm{H}\right\}$ NMR (150.90 MHz, $\left.\mathrm{C}_{6} \mathrm{D}_{6} ; \mathrm{ppm}\right): 138.8$ (br, i-Ph), 133.6 (br, o-Ph), 129.5 (br, $m, p-\mathrm{Ph}), 61.4\left(\mathrm{~m}, \mathrm{PCH}_{2} \mathrm{~N}\right)$, $51.3\left(\mathrm{~m}, \mathrm{NCH}_{2} \mathrm{CH}_{3}\right), 26.8\left(\mathrm{~s}, \mathrm{P}-\mathrm{CH}_{2}\right), 12.6\left(\mathrm{~s}, \mathrm{CH}_{2} \mathrm{CH}_{3}\right) .{ }^{31} \mathrm{P}\left\{{ }^{1} \mathrm{H}\right\}$ NMR (242.94 MHz; $\left.\mathrm{C}_{6} \mathrm{D}_{6} ; \mathrm{ppm}\right)$ : -31.5. MS (ESI +$), m / z,\left(I_{\text {rel }}, \%\right)$ : 647 (100) $[\mathrm{M}+\mathrm{O}+\mathrm{H}]^{+}, 663$ (29) $[\mathrm{M}+2 \mathrm{O}+\mathrm{H}]^{+}, 693$ (15) $[\mathrm{M}+4 \mathrm{O}]^{+}$. Anal. calc. for $\mathrm{C}_{36} \mathrm{H}_{46} \mathrm{~N}_{2} \mathrm{P}_{4}: \mathrm{C}, 68.56 ; \mathrm{H}, 7.35 ; \mathrm{N}$, 4.44; P, 19.65. Found: C, 68.52; H, 7.36; N, 4.45; P, 19.70\%.

After 7 days of standing of $\mathbf{3}_{\mathrm{a}}$ in $\mathrm{C}_{6} \mathrm{D}_{6}$ the signals of dissociation products rac- $\left(\mathbf{3}_{\mathbf{b}}\right)$ and meso- $\left(\mathbf{3}_{\mathbf{c}}\right)$ isomers of 1-ethyl3,6-diphenyl-1-aza-3,6-diphosphacycloheptane 3 prevailed.

Rac-isomer of 1-ethyl-3,6-diphenyl-1-aza-3,6-diphosphacycloheptane $\left(\mathbf{3}_{\boldsymbol{b}}\right)$. ${ }^{1} \mathrm{H}$ NMR (600.13 $\left.\mathrm{MHz} ; \mathrm{C}_{6} \mathrm{D}_{6} ; \mathrm{ppm}\right): 7.34-7.42$ (4 H, br, o-Ph), 7.08-7.15 (6 H, m, $m, p-\mathrm{Ph}), 3.83\left(2 \mathrm{H}, \mathrm{ddd},{ }^{2} J_{\mathrm{HH}}\right.$ 13.7, $\left.{ }^{4} J_{\mathrm{HH}} 4.5,{ }^{2} J_{\mathrm{PH}} 4.5, \mathrm{PCH}_{2} \mathrm{~N}\right), 3.20-3.32\left(2 \mathrm{H}, \mathrm{m}, \mathrm{PCH}_{2} \mathrm{~N}\right)$, 2.60-2.79 (2 H, m, $\mathrm{NCH}_{2} \mathrm{CH}_{3}$ ), 2.00-2.20 (4 H, m, $\left.\mathrm{PCH}_{2}\right), 0.98$ (3 H, t, $\left.{ }^{3} J_{\mathrm{HH}} 7.1, \mathrm{CH}_{2} \mathrm{CH}_{3}\right) .{ }^{13} \mathrm{C}\left\{{ }^{1} \mathrm{H}\right\}$ NMR $\left(150.90 \mathrm{MHz}, \mathrm{C}_{6} \mathrm{D}_{6}\right.$; ppm): 140.2 (dd, ${ }^{1} J_{\mathrm{CP}} 8.2,{ }^{4} J_{\mathrm{CP}} 3.9$, i-Ph), 133.0 (dd, ${ }^{2} J_{\mathrm{CP}} 15.8$, $\left.{ }^{5} J_{\mathrm{CP}} 6.1, o-\mathrm{Ph}\right), 129.4(\mathrm{~m}, m-\mathrm{Ph}), 129.0(\mathrm{~s}, p-\mathrm{Ph}), 61.4\left(\mathrm{~m}, \mathrm{AA}^{\prime} \mathrm{X}\right.$ spin system, $\left.{ }^{1} J_{\mathrm{PC}}-14.1,{ }^{3} J_{\mathrm{PC}} 11.0,{ }^{3} J_{\mathrm{PP}} 13.5, \mathrm{PCH}_{2} \mathrm{~N}\right), 53.9(\mathrm{t}$, $\left.{ }^{3} J_{\mathrm{CP}} 6.0, \mathrm{NCH}_{2} \mathrm{CH}_{3}\right), 28.8\left(\mathrm{~m}, \mathrm{AA}^{\prime} \mathrm{X}\right.$ spin system, ${ }^{1} J_{\mathrm{PC}}-13.8,{ }^{2} J_{\mathrm{PC}}$ 11.9, ${ }^{3} J_{\mathrm{PP}}$ 13.5, $\left.\mathrm{PCH}_{2}\right), 13.9$ (s, $\left.\mathrm{CH}_{2} \mathrm{CH}_{3}\right) .{ }^{31} \mathrm{P}\left\{{ }^{1} \mathrm{H}\right\} \quad \mathrm{NMR}$ (242.94 MHz; $\mathrm{C}_{6} \mathrm{D}_{6}$; ppm): -36.5.

Meso-isomer of 1-ethyl-3,6-diphenyl-1-aza-3,6-diphosphacycloheptane (3 ${ }_{\text {c }}$. ${ }^{1} \mathrm{H}$ NMR (600.13 MHz; $\left.\mathrm{C}_{6} \mathrm{D}_{6} ; \mathrm{ppm}\right): 7.34-7.42$ (4 H, br, o-Ph), 7.08-7.15 (6 H, m, $m, p-\mathrm{Ph}), 3.20-3.32(4 \mathrm{H}, \mathrm{m}$, $\left.\mathrm{PCH}_{2} \mathrm{~N}\right), 2.94\left(2 \mathrm{H}, \mathrm{q},{ }^{3} J_{\mathrm{HH}} 7.1, \mathrm{NCH}_{2} \mathrm{CH}_{3}\right), 2.00-2.20(4 \mathrm{H}, \mathrm{m}$, $\left.\mathrm{PCH}_{2}\right), 1.03\left(3 \mathrm{H}, \mathrm{t},{ }^{3} J_{\mathrm{HH}} 7.1, \mathrm{NCH}_{2} \mathrm{CH}_{3}\right) .{ }^{13} \mathrm{C}\left\{{ }^{1} \mathrm{H}\right\} \quad \mathrm{NMR}$ (150.90 MHz, C $6 \mathrm{D}_{6}$; ppm): 140.9 (dd, ${ }^{1} J_{\mathrm{CP}} 8.5,{ }^{4} J_{\mathrm{CP}} 5.5$, i-Ph), $132.8\left(\mathrm{dd},{ }^{2} J_{\mathrm{CP}} 18.3,{ }^{5} J_{\mathrm{CP}} 9.2, o-\mathrm{Ph}\right), 129.4(\mathrm{~m}, m-\mathrm{Ph}), 129.1(\mathrm{~s}$, p-Ph), $60.8\left(\mathrm{dd},{ }^{1} J_{\mathrm{CP}} 11.7,{ }^{3} J_{\mathrm{CP}} 8.9, \mathrm{P}-\mathrm{CH}_{2}-\mathrm{N}\right), 51.3\left(\mathrm{t},{ }^{3} J_{\mathrm{CP}} 10.2\right.$, $\mathrm{NCH}_{2} \mathrm{CH}_{3}$ ), $24.2\left(\mathrm{~m}, \mathrm{AA}^{\prime} \mathrm{X}\right.$ spin system, ${ }^{1} J_{\mathrm{PC}}-22.1,{ }^{2} J_{\mathrm{PC}} 17.9$, ${ }^{3} J_{\mathrm{PP}}$ 19.5, $\mathrm{PCH}_{2}$ ), $13.8\left(\mathrm{~s}, \mathrm{CH}_{2} \mathrm{CH}_{3}\right) .{ }^{31} \mathrm{P}\left\{{ }^{1} \mathrm{H}\right\} \mathrm{NMR}(242.94 \mathrm{MHz}$;
$\left.\mathrm{C}_{6} \mathrm{D}_{6} ; \mathrm{ppm}\right):-33.5$. MS (ESI+), $m / z,\left(I_{\mathrm{rel}}, \%\right): 316(100)[\mathrm{M}+\mathrm{H}]^{+}$, 332 (203) $[\mathrm{M}+\mathrm{O}+\mathrm{H}]^{+}$.

1,8-Dicyclohexyl-3,6,10,13-tetraphenyl-1,8-diaza-3,6,10,13-tetraphosphacyclotetradecane (4). To the solution of 1 (from $1.1 \mathrm{~g}$ (4.5 mmol) 1,2-bis(phenylphosphino)ethane and $0.27 \mathrm{~g}$ (9.0 mmol) paraform) in $5 \mathrm{ml} \mathrm{DMF}$, cyclohexylamine $(0.44 \mathrm{~g}$, $4.4 \mathrm{mmol}$ ) in $3 \mathrm{ml} \mathrm{DMF}$ was added. The reaction mixture was warmed at $50{ }^{\circ} \mathrm{C}$ for 1 hour. After cooling the precipitated white crystals were filtered off and washed 2 times with $5 \mathrm{ml}$ ethanol. Yield: $0.33 \mathrm{~g}, \quad 20 \%$, mp $157-159{ }^{\circ} \mathrm{C} .{ }^{1} \mathrm{H} \quad \mathrm{NMR}$ (600.13 MHz; $\mathrm{C}_{6} \mathrm{D}_{6}$; ppm): 7.53 (8 H, br, o-Ph), 7.04-7.07 (12 H, $\mathrm{m}, m, p-\mathrm{Ph}), 3.68\left(4 \mathrm{H}, \mathrm{dd},{ }^{2} J_{\mathrm{HH}} 12.4,{ }^{2} J_{\mathrm{PH}} 5.4, \mathrm{PCH}_{2} \mathrm{~N}\right), 3.61$ (2 H, t, $\left.{ }^{3} J_{\mathrm{HH}} 9.0,1-\mathrm{H}(c \mathrm{Hex})\right), 2.82\left(4 \mathrm{H}, \mathrm{br} \mathrm{m}, \mathrm{PCH}_{2}\right), 2.68(4 \mathrm{H}$, dd, $\left.{ }^{2} J_{\mathrm{HH}} 12.4,{ }^{2} J_{\mathrm{PH}} 19.5, \mathrm{PCH}_{2} \mathrm{~N}\right), 2.22\left(4 \mathrm{H}\right.$, br m, $\mathrm{PCH}_{2}$ ), $2.04(2 \mathrm{H}, \mathrm{br}, 2-\mathrm{H}(c \mathrm{Hex})), 1.88$ (2 H, br, 3-H $(c \mathrm{Hex})), 1.74(2 \mathrm{H}$, $\mathrm{d},{ }^{2} J_{\mathrm{HH}} 11.6,2$ '-H $\left.(c \mathrm{Hex})\right), 1.68\left(2 \mathrm{H}, \mathrm{d},{ }^{2} J_{\mathrm{HH}} 13.1,33^{\prime}-\mathrm{H}(c \mathrm{Hex})\right)$, $1.61\left(2 \mathrm{H}, \mathrm{d},{ }^{2} J_{\mathrm{HH}} 12.6,3-\mathrm{H}(c \mathrm{Hex})\right), 1.47$ (4 H, br, 2,4-H (cHex)), $1.21\left(2 \mathrm{H}, \mathrm{dt},{ }^{2} J_{\mathrm{HH}} 13.1,{ }^{3} J_{\mathrm{HH}} 12.4,3^{\prime}-\mathrm{H}(c \mathrm{Hex})\right), 1.02(2 \mathrm{H}, \mathrm{dt}$, $\left.{ }^{2} J_{\mathrm{HH}} 12.8,{ }^{3} J_{\mathrm{HH}} 9.3,4-\mathrm{H}(c \mathrm{Hex})\right), 0.79\left(2 \mathrm{H}, \mathrm{dt},{ }^{2} J_{\mathrm{HH}} 12.4,{ }^{3} J_{\mathrm{HH}}\right.$ $\left.11.9 \mathrm{~Hz}, 2^{\prime}-\mathrm{H}(c \mathrm{Hex})\right) .{ }^{13} \mathrm{C}\left\{{ }^{1} \mathrm{H}\right\}$ NMR (150.90 MHz, $\left.\mathrm{C}_{6} \mathrm{D}_{6} ; \mathrm{ppm}\right)$ : 138.9 (s, i-Ph), 133.7 (dd, $\left.{ }^{2} J_{\mathrm{CP}} 10.0,{ }^{5} J_{\mathrm{CP}} 8.0, o-\mathrm{Ph}\right), 129.6$ (s, m$\mathrm{Ph}), 129.4$ (s, p-Ph), $60.4(\mathrm{~s}, \mathrm{C}-1(c \mathrm{Hex})), 57.8\left(\mathrm{~s}, \mathrm{PCH}_{2} \mathrm{~N}\right), 33.4$ (s, C-2 (cHex)), 27.6 (s, C-3 (cHex)), 27.4 (s, C-4 (cHex)), 27.1 (br, $\mathrm{PCH}_{2}$ ), 26.9 (s, C-3' (cHex)), 24.2 (br, C-2' (cHex)). ${ }^{31} \mathrm{P}\left\{{ }^{1} \mathrm{H}\right\}$ NMR (242.94 MHz; $\left.\mathrm{C}_{6} \mathrm{D}_{6} ; \mathrm{ppm}\right):-31.7$. MS (ESI+), $\mathrm{m} / \mathrm{z},\left(I_{\mathrm{rel}}, \%\right): 370$ (100) $[1 / 2 \mathrm{M}+\mathrm{H}]^{+}, 755$ (36) $[\mathrm{M}+\mathrm{O}+\mathrm{H}]^{+}$. Anal. calc. for $\mathrm{C}_{44} \mathrm{H}_{58} \mathrm{~N}_{2} \mathrm{P}_{4}$ : C, 71.53; H, 7.91; N, 3.79; P, 16.77\%. Found: C, 71.51 ; H, 7.92; N, 3.75; P, 16.70.

After 5 days of standing of $\mathbf{4}_{a}$ in $\mathrm{C}_{6} \mathrm{D}_{6}$ the signals of dissociation products rac- $\left(\mathbf{4}_{\mathbf{b}}\right)$ and meso- $\left(\mathbf{4}_{\mathbf{c}}\right)$ isomers of 1-cyclohexyl-3,6-diphenyl-1-aza-3,6-diphosphacycloheptane 4 prevailed.

Rac-isomer of 1-cyclohexyl-3,6-diphenyl-1-aza-3,6-diphosphacycloheptane $\left(\boldsymbol{4}_{\boldsymbol{b}}\right) .{ }^{1} \mathrm{H}$ NMR (600.13 $\left.\mathrm{MHz} ; \mathrm{C}_{6} \mathrm{D}_{6} ; \mathrm{ppm}\right): 7.47$ (4 H, br, o-Ph), 7.07-7.14 (6 H, m,p-Ph), $3.87\left(2 \mathrm{H}\right.$, ddd, ${ }^{2} J_{\mathrm{HH}}$ 13.7, $\left.{ }^{2} J_{\mathrm{PH}} 4.2,{ }^{4} J_{\mathrm{HH}} 4.2, \mathrm{PCH}_{2} \mathrm{~N}\right), 3.38\left(2 \mathrm{H}, \mathrm{d},{ }^{2} J_{\mathrm{HH}} 13.7\right.$, $\mathrm{PCH}_{2} \mathrm{~N}$ ), 2.52 (1 H, m, 1-H (cHex)), 2.08-2.24 (4 H, m, P- $\left.\mathrm{CH}_{2}\right)$, 2.00-2.08 (1 H, m, 2-H (cHex)), 1.85-1.98 (1 H, m, 2'-H (cHex)), 1.57-1.71 (2 H, m, 3,3'-H (cHex)), 1.45 (1 H, br, 4-H (cHex)), 1.04-1.32 (4 H, m, 2,2',3,3'-H (cHex)), 0.90-1.02 (1 H, m, 4-H (cHex)). ${ }^{13} \mathrm{C}\left\{{ }^{1} \mathrm{H}\right\}$ NMR (150.90 MHz, $\mathrm{C}_{6} \mathrm{D}_{6}$; ppm): 140.6 (dd, ${ }^{1} J_{\mathrm{CP}}$ 9.7, ${ }^{4} J_{\mathrm{CP}} 4.3$, i-Ph), 133.1 (ddd, $\left.{ }^{2} J_{\mathrm{CP}} 18.7,{ }^{5} J_{\mathrm{CP}} 9.8, o-\mathrm{Ph}\right), 129.4$ (m, m-Ph), 129.0 (m, p-Ph), 66.0 (s, C-1 (cHex)), 58.1 (m, AA'X spin system, $\left.{ }^{1} J_{\mathrm{PC}}-14.2,{ }^{3} J_{\mathrm{PC}} 10.8,{ }^{3} J_{\mathrm{PP}} 12.9, \mathrm{PCH}_{2} \mathrm{~N}\right), 31.19$ (s, C-2 (cHex)), 31.14 (s, C-2' (cHex)), 28.0 (m, AA'X spin system, $\left.{ }^{1} J_{\mathrm{PC}}-14.2,{ }^{2} J_{\mathrm{PC}} 12.2,{ }^{3} J_{\mathrm{PP}} 12.9, \mathrm{PCH}_{2}\right), 27.1$ (s, C-4 (cHex), 26.7 (s, C-3 (cHex)), 26.6 (s, C-3' (cHex)). ${ }^{31} \mathrm{P}\left\{{ }^{1} \mathrm{H}\right\}$ NMR (242.94 MHz; $\left.\mathrm{C}_{6} \mathrm{D}_{6} ; \mathrm{ppm}\right):-30.0$.

Meso-isomer of 1-cyclohexyl-3,6-diphenyl-1-aza-3,6-diphosphacycloheptane (4). ${ }^{1} \mathrm{H}$ NMR (600.13 MHz; $\left.\mathrm{C}_{6} \mathrm{D}_{6} ; \mathrm{ppm}\right): 7.41$ (4 H, br, o-Ph), 7.07-7.14 (6 H, $m, p-\mathrm{Ph}), 3.45\left(2 \mathrm{H}, \mathrm{m}, \mathrm{PCH}_{2} \mathrm{~N}\right)$, $3.05\left(2 \mathrm{H}, \mathrm{d},{ }^{2} J_{\mathrm{HH}} 14.2, \mathrm{PCH}_{2} \mathrm{~N}\right), 2.78(1 \mathrm{H}, \mathrm{m}, 1-\mathrm{H}(c \mathrm{Hex}))$, 2.08-2.24 (4 H, m, PCH $H_{2}$, 1.85-1.98 (2 H, m, 2-H (cHex)), 1.57-1.71 (2 H, m, 3-H (cHex)), 1.45 (1 H, br, 4-H (cHex)), 1.04-1.32 (2 H, m, 3-H (cHex)), 0.90-1.02 (1 H, m, 4-H (cHex)). ${ }^{13} \mathrm{C}\left\{{ }^{1} \mathrm{H}\right\}$ NMR (150.90 MHz, $\left.\mathrm{C}_{6} \mathrm{D}_{6} ; \mathrm{ppm}\right): 141.2$ (dd, ${ }^{1} J_{\mathrm{CP}}$ 10.7, ${ }^{4} J_{\mathrm{CP}}$ 6.5, i-Ph), 132.7 (dd, $\left.{ }^{2} J_{\mathrm{CP}} 8.7,{ }^{5} J_{\mathrm{CP}} \quad 5.5, o-\mathrm{Ph}\right), 129.4$ 
(m, m-Ph), 129.0 (m, p-Ph), 64.0 (s, C-1 (cHex)), 57.5 (dd, $\left.{ }^{1} J_{\mathrm{CP}}-8.7,{ }^{3} J_{\mathrm{CP}} 5.1, \mathrm{PCH}_{2} \mathrm{~N}\right), 30.8(\mathrm{~s}, \mathrm{C}-2(c \mathrm{Hex})), 27.0(\mathrm{~s}, \mathrm{C}-4$ $(c$ Hex $)), 26.5$ (s, C-3 (cHex)), 23.4 (m, AA'X spin system, $\left.{ }^{1} J_{\mathrm{PC}} \quad-22.2, \quad{ }^{2} J_{\mathrm{PC}} \quad 15.2, \quad{ }^{3} J_{\mathrm{PP}} \quad 20.1, \quad \mathrm{PCH}_{2}\right) . \quad{ }^{31} \mathrm{P}\left\{{ }^{1} \mathrm{H}\right\} \quad \mathrm{NMR}$ (242.94 MHz; $\left.\mathrm{C}_{6} \mathrm{D}_{6} ; \mathrm{ppm}\right):-26.2$. MS (ESI +$), m / z,\left(I_{\text {rel }}, \%\right): 370$ (100) $[\mathrm{M}+\mathrm{H}]^{+}$.

\section{X-ray crystallography data}

The crystals of 2a suitable for X-ray diffraction were hand selected from precipitates that separated from the reaction mixtures. The data of 2 a were collected on a Gemini diffractometer (Agilent Technologies) using MoK $\alpha$ radiation $(\lambda=$ $0.71073 \AA$ ) and $\omega$-scan rotation. Data reduction was performed with CrysAlis-Pro ${ }^{20}$ including the program SCALE3 ABSPACK for empirical absorption correction. The structure was solved by direct methods (SIR92) ${ }^{21}$ and the refinement was performed with SHELXL-2014. ${ }^{22}$ The molecule is located at a special position $\left(C_{2}\right.$ axis). All non-hydrogen atoms were refined with anisotropic thermal parameters. A difference-density Fourier map was used to locate all hydrogen atoms in the final stage of the structure refinement. Fig. 2 was generated with Diamond. ${ }^{23}$ CCDC 1060031 contains the supplementary crystallographic data for this paper.

\section{Acknowledgements}

This work was supported by the Russian Foundation for Basic Researches (No. 13-03-00169, 15-43-02292), President's of RF Grant for the support of leading Scientific schools No. 4428.2014.3 and Programs of Russian Academy of Sciences.

\section{Notes and references}

1 A. A. Karasik and O. G. Sinyashin, in Phosphorus Compounds Advanced Tools in Catalysis and Material Sciences, ed. M. Peruzzini and L. Gonsalvi, Springer, Netherlands, 2011, ch. 37, vol. 12, pp. 375-444.

2 (a) A.-M. Caminade and J. P. Majoral, Chem. Rev., 1994, 94, 1183; (b) A.-M. Caminade and J. P. Majoral, Synlett, 1996, 1019; (c) M. Pabel and B. Wild, Compr. Heterocycl. Chem. II, 1996, 947; (d) I. Bauer, W. D. Habicher, I. S. Antipin and O. G. Sinyashin, Russ. Chem. Bull., 2004, 53, 1402; (e) V. Simulescu and G. Ilia, J. Inclusion Phenom. Macrocyclic Chem., 2010, 66, 3.

3 C. D. Swor and D. R. Tyler, Coord. Chem. Rev., 2011, 255, 2860.

4 (a) C. Toulhoat, M. Vidal and M. Vincens, Phosphorus, Sulfur Silicon Relat. Elem., 1992, 71, 127; (b) B. Lambert and J. F. Desreux, Synthesis, 2000, 1668.

5 A. J. Churchard, E. Banach, A. Borgschulte, R. Caputo, J.-C. Chen, D. Clary, K. J. Fijalkowski, H. Geerlings, R. V. Genova, W. Grochala, T. Jaroń, J. C. Juanes-Marcos, B. Kasemo, G.-J. Kroes, I. Ljubić, N. Naujoks, J. K. Nørskov, R. A. Olsen, F. Pendolino, A. Remhof, L. Románszki,
A. Tekin, T. Vegge, M. Zäch and A. Züttel, Phys. Chem. Chem. Phys., 2011, 13, 16955-16972.

6 M. T. Mock, S. Chen, M. O’Hagan, R. Rousseau, W. G. Dougherty, W. S. Kassel and R. M. Bullock, J. Am. Chem. Soc., 2013, 11493-11496.

7 (a) A. A. Karasik, A. S. Balueva and O. G. Sinyashin, C. R. Chim., 2010, 13, 1151; (b) D. V. Kulikov, A. A. Karasik, A. S. Balueva, O. N. Kataeva, I. A. Livinov, E. Hey-Hawkins and O. G. Sinyashin, Mendeleev Commun., 2007, 17, 195; (c) A. S. Balueva, D. V. Kulikov, R. M. Kuznetsov, A. T. Gubaidullin, L. Ricard, A. A. Karasik and O. G. Sinyashin, J. Inclusion Phenom. Macrocyclic Comp., 2008, 60, 321; (d) R. N. Naumov, A. A. Karasik, K. B. Kanunnikov, A. V. Kozlov, S. K. Latypov, K. V. Domasevitch, E. Hey-Hawkins and O. G. Sinyashin, Mendeleev Commun., 2008, 18, 80; (e) R. N. Naumov, A. A. Karasik, O. G. Sinyashin, P. Lönnecke and E. HeyHawkins, Dalton Trans., 2004, 357; (f) A. A. Karasik, D. V. Kulikov, A. S. Balueva, S. N. Ignat'eva, O. N. Kataeva, P. Lönnecke, A. V. Kozlov, S. K. Latypov, E. Hey-Hawkins and O. G. Sinyashin, Dalton Trans., 2009, 490; (g) R. N. Naumov, A. V. Kozlov, K. B. Kanunnikov, S. Gomez-Ruiz, E. Hey-Hawkins, S. K. Latypov, A. A. Karasik and O. G. Sinyashin, Tetrahedron Lett., 2010, 51, 1034; (h) A. A. Karasik, D. V. Kulikov, R. M. Kuznetsov, A. S. Balueva, S. N. Ignat'eva, O. N. Kataeva, P. Lönnecke, O. G. Sharapov, S. K. Latypov, E. Hey-Hawkins and O. G. Sinyashin, Macroheterocycles, 2011, 4, 324.

8 (a) A. A. Karasik, A. S. Balueva, E. I. Moussina, R. N. Naumov, A. B. Dobrynin, D. B. Krivolapov, I. A. Litvinov and O. G. Sinyashin, Heteroat. Chem., 2008, 9, 125-132; (b) E. I. Musina, A. A. Karasik, A. S. Balueva, I. D. Strelnik, T. I. Fesenko, A. B. Dobrynin, T. P. Gerasimova, S. A. Katsyuba, O. N. Kataeva, P. Lönnecke, E. Hey-Hawkins and O. G. Sinyashin, Eur. J. Inorg. Chem., 2012, 1857; (c) T. I. Fesenko, I. D. Strelnik, E. I. Musina, A. A. Karasik and O. G. Sinyashin, Russ. Chem. Bull., 2012, 61, 1792.

9 (a) R. N. Naumov, E. I. Musina, K. B. Kanunnikov, T. I. Fesenko, D. B. Krivolapov, I. A. Litvinov, P. Lönnecke, E. Hey-Hawkins, A. A. Karasik and O. G. Sinyashin, Dalton Trans., 2014, 43, 12784-12789; (b) A. A. Karasik, R. N. Naumov, K. B. Kanunnikov, D. B. Krivolapov, I. A. Litvinov, P. Lönnecke, A. S. Balueva, E. I. Musina, E. Hey-Hawkins and O. G. Sinyashin, Macroheterocycles, 2014, 7, 181-188.

10 A. E. Derome, Modern NMR Techniques for Chemistry Research, Pergamon, Cambridge, U.K., 1988.

11 Atta-ur-Rahman, One and Two Dimensional NMR Spectroscopy, Elsevier, Amsterdam, 1989.

12 W. S. Price, Concepts Magn. Reson., 1997, 9, 299-336; W. S. Price, Concepts Magn. Reson., 1998, 10, 197-237.

13 C. S. Johnson, Prog. Nucl. Magn. Reson. Spectrosc., 1999, 34, 203-256.

14 K. Stott, J. Stonehouse, J. Keeler, T. L. Hwang and A. J. Shaka, J. Am. Chem. Soc., 1995, 117, 4199-4200. 
15 (a) Sh. K. Latypov, A. V. Kozlov, E. Hey-Hawkins, A. S. Balueva, A. A. Karasik and O. G. Sinyashin, J. Phys. Chem. A, 2010, 114, 2588-2596; (b) S. K. Latypov, A. G. Strelnik, S. N. Ignatieva, E. Hey-Hawkins, A. S. Balueva, A. A. Karasik and O. G. Sinyashin, J. Phys. Chem. A, 2012, 116, 3182-3193.

16 S. V. Kharlamov and S. K. Latypov, Russ. Chem. Rev., 2010, 79, 635-653.

17 (a) M. P. Stewart, M.-H. Ho, S. Wiese, M. L. Lindstrom, C. E. Thogerson, S. Raugei, R. M. Bullock and M. L. Helm, J. Am. Chem. Soc., 2013, 135, 6033-6046; (b) M. H. Helm, M. P. Stewart, R. M. Bullock, M. Rakowski DuBois and D. L. Dubois, Science, 2011, 333, 863-8662; (c) M. L. Reback, G. W. Buchko, B. L. Kier, B. Ginovska-Pangovska, Y. Xiong, S. Lense, J. Hou, J. A. S. Roberts, C. M. Sorensen, S. Raugei, T. C. Squier and W. J. Shaw, Chem. - Eur. J., 2014, 20, 1510; (d) R. M. Galimullina, M. I. Valitov, Y. S. Spiridonova, E. I. Musina, S. A. Krasnov, M. K. Kadirov, A. A. Karasik, Y. G. Budnikova and O. G. Sinyashin, Russ. J. Phys. Chem., 2011, 85, 2214.

18 M. J. Frisch, G. W. Trucks, H. B. Schlegel, G. E. Scuseria, M. A. Robb, J. R. Cheeseman, J. A. Montgomery Jr., T. Vreven, K. N. Kudin, J. C. Burant, J. M. Millam, S. S. Iyengar, J. Tomasi, V. Barone, B. Mennucci, M. Cossi, G. Scalmani, N. Rega, G. A. Petersson, H. Nakatsuji, M. Hada, M. Ehara, K. Toyota, R. Fukuda, J. Hasegawa,
M. Ishida, T. Nakajima, Y. Honda, O. Kitao, H. Nakai, M. Klene, X. Li, J. E. Knox, H. P. Hratchian, J. B. Cross, C. Adamo, J. Jaramillo, R. Gomperts, R. E. Stratmann, O. Yazyev, A. J. Austin, R. Cammi, C. Pomelli, J. W. Ochterski, P. Y. Ayala, K. Morokuma, G. A. Voth, P. Salvador, J. J. Dannenberg, V. G. Zakrzewski, S. Dapprich, A. D. Daniels, M. C. Strain, O. Farkas, D. K. Malick, A. D. Rabuck, K. Raghavachari, J. B. Foresman, J. V. Ortiz, Q. Cui, A. G. Baboul, S. Clifford, J. Cioslowski, B. B. Stefanov, G. Liu, A. Liashenko, P. Piskorz, I. Komaromi, R. L. Martin, D. J. Fox, T. Keith, M. A. Al-Laham, C. Y. Peng, A. Nanayakkara, M. Challacombe, P. M. W. Gill, B. Johnson, W. Chen, M. W. Wong, C. Gonzalez and J. A. Pople, GAUSSIAN 03 (Revision A.1), Gaussian, Inc., Pittsburgh PA, 2003.

19 S. K. Latypov, F. M. Polyancev, D. G. Yakhvarov and O. G. Sinyashin, Phys. Chem. Chem. Phys., 2015, 17, 69766987.

20 CrysAlis-Pro: Data collection and data reduction software package, Agilent Technologies.

21 A. Altomare, G. Cascarano, C. Giacovazzo and A. Guagliardi, J. Appl. Crystallogr., 1994, 27, 435.

22 G. M. Sheldrick, Acta Crystallogr., Sect. C: Cryst. Struct. Commun., 2015, 71, 3-8.

23 K. Brandenburg, DIAMOND (Version 3.2k), Crystal Impact GbR, Bonn, Germany. 